\title{
Growth and mortality of Cachana (Cynopotamus atratoensis) in the cienaga Grande de Lorica, Colombia
}

\section{Crecimiento y mortalidad de la Cachana (Cynopotamus atratoensis) en la ciénaga Grande de Lorica, Colombia}

\author{
Charles Olaya-Nieto ${ }^{1 *}$, M.Sc, Fredys Segura-Guevara, ${ }^{1}$ M.Sc, \\ Antonio Vergara-Paternina, ${ }^{1}$ Prof. Acuicul. \\ ${ }^{1}$ Universidad de Córdoba, Facultad de Medicina Veterinaria y Zootecnia, Departamento de Ciencias \\ Acuícolas, Laboratorio de Investigación Biológico Pesquera-LIBP. Cra 23 No. 2A-20, Piso 2. Lorica, \\ Colombia. *Correspondencia: charles_olaya@hotmail.com
}

Received: June 2014; Acepted: February 2015.

\begin{abstract}
Objective. Growth and mortality parameters of Cachana Cynopotamus atratoensis Eigenmann, 1907 in the cienaga Grande de Lorica, Sinu river basin, Colombia, were estimated. Materials and methods. The length frequency analysis to the information collected between January 2001 to December 2002, was applied. Results. The estimated values for asymptotic length, growth rate and age at zero length were $43.4( \pm 0.52) \mathrm{cm}$ of total length, $0.29( \pm 0.02)$ year $^{-1}$ and -0.53 years, respectively. Total mortality was estimated at 0.97 year $^{-1}$, natural mortality at 0.72 year $^{-1}$, fishing mortality at 0.25 , the average catch size was $24.8 \mathrm{~cm}$ total length, being fully recruited to the fishery with $16.6 \mathrm{~cm}$ total length, with low exploitation rate (E: 0.26). Conclusions. Cachana is a fish with medium longevity and growth rate with low exploitation rate, suggesting that there is still no overfishing on the species. However, as it is an very important fish in the food security of fishermen and their families, its necessary to increase the basic biology research pointing to the management and conservation of the species in the cienaga and the Sinu basin.
\end{abstract}

Key words: Conservation, exploitation rate, management, migration, overfishing (Source: ASFA).

\section{RESUMEN}

Objetivos. Estimar los parámetros de crecimiento y mortalidad de la Cachana Cynopotamus atratoensis Eigenmann, 1907 en la ciénaga Grande de Lorica, cuenca del río Sinú, Colombia. Materiales y métodos. Se aplicó el análisis de frecuencia de tallas a la información colectada en el período comprendido entre enero 2001 y diciembre 2002. Resultados. Los valores estimados para la longitud asintótica, tasa de crecimiento y edad a la longitud cero fueron $43.4( \pm 0.52) \mathrm{cm}$ de longitud total, 0.29 ( \pm 0.02$)$ año-1 y -0.53 años, respectivamente. La mortalidad total fue estimada en 0.97 año-1, la mortalidad natural en 0.72 año-1 $^{-1}$ la mortalidad por pesca en $0.25 \mathrm{año}^{-1}$, la talla media de captura fue $24.8 \mathrm{~cm}$ de longitud total, siendo reclutada totalmente a la pesquería con $16.6 \mathrm{~cm}$ de longitud total, con baja tasa de explotación $(E=0.26)$. Conclusiones. La Cachana es un pez de longevidad y tasa de crecimiento medios con baja tasa de explotación, lo que sugiere que aún no hay sobrepesca sobre la especie. Sin embargo, como es un pez muy importante en la seguridad alimentaria de los pescadores y sus familias, es necesario incrementar la investigación sobre su biología básica apuntando al manejo y conservación de la especie en la ciénaga y la cuenca del Sinú.

Palabras clave: Conservación, manejo, migración, sobrepesca, tasa de explotación (Fuente: AIMS). 


\section{INTRODUCTION}

Cachana Cynopotamus atratoensis (1) is a carnivorous fish found in the Ciénaga Grande de Lorica. Its main habitat is in the basin of the Sinú River, where they are mainly caught, with a maximum length of $45.3 \mathrm{~cm}$ TL and maximum weight of $1.1 \mathrm{~kg}$.

It feeds mainly on fish such as Yalúa Cyphocharax magdalenae, Mayupa Sternopygus macrurus, Chipe Hoplosternum magdalenae, and others of its same species, indicating a tendency towards cannibalism. It maintains its preferences as it grows, year-round, and the swamp's hydrological cycle, with a $r^{2}$ type reproductive strategy and two periods of spawning and high fertility levels.

The objective of this work was to estimate the growth and mortality parameters of the Cachana in the Ciénaga Grande de Lorica Sinú River basin to contribute to the knowledge of its lifecycle, fishery procedures and species management and conservation in the swamp and the Sinú basin.

\section{MATERIALS AND METHODS}

Area of study. This research took place in the Ciénaga Grande de Lorica, wetlands located $9^{\circ}$ north latitude and $75^{\circ} 40^{\prime}$ west longitude, downstream of the Urra dam and on the right border of the Sinú River, Colombia, connected by the Bugre and Aguas Prietas streams.

Sampling. The information was taken between January 2001 and December 2002. Some samples were collected by researchers involved in the project and the rest were taken by fishermen in their work in the study area, which were given to the laboratory. Only cast nest catches were considered, a type of fishing that makes it possible to obtain different size samples and thus avoids biases due to selectivity. The following measurements were taken for each individual: total length ( $T L$ ), fork length (FL) and standard length ( $\mathrm{SL}$ ) to the closest millimeter with a graduated ictiometer (Tridente, Spain) and total weight (TW) to the closest gram with an electric scale (Ohaus, USA) with a $5000( \pm 0.1)$ g capacity.

Estimating growth parameters. The information was truncated to avoid biases in the estimates. The class interval used was 1 $\mathrm{cm}$ to obtain the length frequency distribution, which was run through the normality test (2). Initially the growth coefficient was estimated (b) for the total length-total weight relationship for the samples collected, using the Student test to establish if it was isometric or allometric.

\section{INTRODUCCIÓN}

La Cachana Cynopotamus atratoensis (1) es un pez carnívoro residente en la ciénaga Grande de Lorica, su hábitat principal en cuenca del río Sinú, Colombia y área en donde se presentan las mayores capturas de la especie, registrándose una talla máxima de $45.3 \mathrm{~cm}$ LT y un peso máximo de $1.1 \mathrm{~kg}$.

Se alimenta principalmente de peces como Yalúa Cyphocharax magdalenae, Mayupa Sternopygus macrurus, Chipe Hoplosternum magdalenae, y algunos de su misma especie, lo que denota conducta caníbal. Mantiene sus preferencias por los peces a medida que va creciendo, a lo largo del año y del ciclo hidrológico de la ciénaga, presentando estrategia reproductiva del tipo $r^{2}$, con dos períodos de desove y alta fecundidad.

El objetivo de este trabajo fue estimar los parámetros de crecimiento y mortalidad de la Cachana en la ciénaga Grande de Lorica, cuenca del río Sinú, como contribución al conocimiento de su ciclo de vida, al ordenamiento de su pesquería y al manejo y conservación de la especie en la ciénaga y en la cuenca del Sinú.

\section{MATERIALES Y MÉTODOS}

Área de estudio. Esta investigación se desarrolló en la ciénaga Grande de Lorica, humedal ubicado a los $9^{\circ}$ de latitud Norte y $75^{\circ} 40^{\prime}$ de longitud Oeste, aguas abajo de la represa de Urrá y en la margen derecha del río Sinú, Colombia al cual se conecta mediante los caños Bugre y Aguas Prietas.

Muestras. La información fue tomada entre enero 2001 y diciembre 2002. Parte de las muestras fue colectada por los investigadores involucrados en el proyecto y el resto por los pescadores en las faenas que efectúan en el área de estudio, las cuales fueron cedidas al laboratorio. Solo se consideraron las capturas con atarraya, arte de pesca que permite obtener ejemplares de diferentes tallas, evitando que se presenten sesgos en las mismas debido a la selectividad del arte. Las mediciones que se tomaron para cada ejemplar fueron: longitud total (LT), longitud horquilla (LH) y longitud estándar (LS) al milímetro más cercano con un ictiómetro graduado (Tridente, España) y peso total (WT) al gramo más cercano con una balanza eléctrica (Ohaus, USA) con capacidad de 5000 ( \pm 0.1$) \mathrm{g}$.

Estimación de los parámetros de crecimiento. La información se truncó para evitar sesgos en las estimaciones. El intervalo de clase utilizado fue de $1 \mathrm{~cm}$ para obtener la distribución de frecuencia de tallas, a la cual se le realizó la prueba de normalidad (2). Inicialmente se estimó el coeficiente de crecimiento (b) de la relación longitud total-peso 
The linear regressions estimated were standard length-total length (SL-TL), fork length-total length (FL-TL) and standard length-fork length (SL-FL), applying the least squares methods (3):

$y=a+b x$

Where $y$ is the dependent variable in centimeters, $a$ is the regression intercept, $b$ is the regression slope and $x$ is the independent variable in centimeters.

ELEFAN I (4) was applied to the distribution of length frequency to estimate the asymptotic length $\left(L_{\text {inf }}\right)$ and the growth coefficient $(K)$ for the Von Bertalanffy equation (5), corrected since the growth coefficient was allometric:

$L_{t}=L_{\text {inf }}\left\{1-e^{\left[-K^{*} D(t-t o)\right] 1 / D}\right\}$

Where $L_{t}$ is the average length at age $t, L_{\text {inf }}$ is the asymptotic length or the maximum theoretical length size that the fish can reach, $K$ is the coefficient to reach $L_{\text {inf }}$ D is equal to 3 [ $1-(0.6742$ $\left.\left.+0.03574 * \log _{10} T W_{\text {Máx }}\right)\right], \mathrm{TW}_{\text {Máx }}$ is the highest weight collected and $t_{0}$ the "age" at zero length. Different combinations were applied to the growth parameters ( $\mathrm{L}_{\text {inf }}$ and $\mathrm{K}$ ) in an attempt to seek the best adjustment possible for the data set, selecting 10 pairs, estimating measurements and standard deviation for each parameter.

It should be noted that $t_{0}$ cannot be estimated applying the length frequency analysis, including ELEFAN, so it was obtained through this empirical equation (3):

$\log _{10}\left(-t_{0}\right)=-0.3922-0.2752 \log _{10} L_{\text {inf }}-1.038$ $\log _{10} K$

To check if this parameter was different from zero, the Student test was applied. Finally, the empirical equation of the growth performance index $\left(\varnothing^{\prime}\right)(6)$ was estimated, which makes it possible to compare different estimates of growth parameters within the species, order or family:

$\left(\varnothing^{\prime}\right)=\log _{10} K+2 \log _{10} L_{\text {inf }}$

Estimation of mortality parameters. The instantaneous rate of total mortality Z) was estimated using the length converted in catch curve method (3) with the following equation:

Loge $(N / \Delta t)=a+b t$

Where e is the base of the neperian logarithm, $\mathrm{N}$ is the number of fish in the sample, $\Delta \mathrm{t}$ is the interval necessary for the fish to go from one total de la muestra colectada, utilizando el test de Student para establecer si era isométrico o alométrico.

Se estimaron las regresiones lineales longitud estándar-longitud total (LS-LT), longitud horquillalongitud total (LH-LT) y longitud estándar-longitud horquilla (LS-LH), aplicando el método de los mínimos cuadrados (3):

$y=a+b x$

En donde y es la variable dependiente en centímetros, a es el intercepto de la regresión, b es la pendiente de la regresión y $\mathrm{x}$ es la variable independiente en centímetros.

Se aplicó ELEFAN I (4) a la distribución de frecuencia de tallas para estimar la longitud asintótica $\left(\mathrm{L}_{\text {inf }}\right)$ y el coeficiente de crecimiento (K) de la ecuación de Von Bertalanffy (5), corregida debido a que el coeficiente de crecimiento fue alométrico:

$L_{t}=L_{\text {inf }}\left\{1-e^{[-K * D(t-t o)] 1 / D}\right\}$

En donde, $L_{t}$ es la longitud media a la edad $t$, $L_{\text {inf }}$ es la longitud asintótica o la máxima talla teórica que puede alcanzar el pez, $\mathrm{K}$ es el coeficiente con el cual se alcanza $L_{\text {inf }} D$ es igual a 3 [1- $(0.6742$ $\left.+0.03574 * \log _{10} \mathrm{WT}_{\text {Máx }}\right)$, $\mathrm{WT}_{\text {Máx }}$ es el mayor peso colectado y $t_{0}$ la "edad" a la longitud cero. Se aplicaron diferentes combinaciones de los parámetros de crecimiento $\left(\mathrm{L}_{\text {inf }}\right.$ y $\left.\mathrm{K}\right)$, tratando de buscar el mejor ajuste posible para la serie de datos, seleccionándose 10 parejas, estimándose la media y la desviación estándar para cada parámetro.

Cabe notar que $t_{0}$ no se puede estimar aplicando análisis de frecuencia de tallas, incluido ELEFAN, por tanto se obtuvo mediante la ecuación empírica (3):

$\log _{10}\left(-t_{0}\right)=-0.3922-0.2752 \log _{10} L_{\text {inf }}-1.038$ $\log _{10} \mathrm{~K}$

Para comprobar si este parámetro era diferente de cero se le aplicó el test de Student. Finalmente, se estimó la ecuación empírica del Índice de desempeño del crecimiento $\left(\varnothing^{\prime}\right)(6)$, índice que permite efectuar comparaciones de las diferentes estimaciones de los parámetros de crecimiento dentro de la especie, género o familia:

$\left(\varnothing^{\prime}\right)=\log _{10} K+2 \log _{10} L_{\text {inf }}$

Estimación de los parámetros de mortalidad. La tasa instantánea de mortalidad total ( $Z$ ) se estimó con el método de tallas convertidas en curvas de captura (3) con la siguiente ecuación:

Loge $(N / \Delta t)=a+b t$ 
length to the next, $a$ is the regression intercept, $b$ is the regression slope and $t$ is the relative average age. The catch curve was based on the estimated average values for growth parameters, tracing the regression line above the points located in the descending part of the curve where the instantaneous mortality rate $(Z)$ is the slope (b) with changed signs. The confidence interval at $95 \%$ and the coefficient of determination were obtained using only the values in $x$ e $y$ involved in the regression.

The instantaneous rate of natural mortality (M) was estimated with the equation (3):

$$
\begin{aligned}
& \log _{10} M=-0.0066-0.279 \log _{10} L_{\text {inf }}+0.6543 \\
& \log _{10} K+0.4634 \log _{10} T
\end{aligned}
$$

Where $T$ is the average annual water temperature, measured with portable multi parametric equipment (Hanna Instruments, USA). The instantaneous rate of fishing mortality $(F)$ was calculated with $\mathrm{F}=\mathrm{Z}-\mathrm{M}$ and the exploitation rate (E) was obtained with the relation $E=F / Z$, routines that are part of ELEFAN II (4). To estimate the pattern of selection and recruitment, the Tresierra \& Culquichicón (7) method was applied using asymptotic length data $\left(\mathrm{L}_{\text {inf }}\right)$, growth coefficient $(K)$ and the age at zero length $\left(t_{0}\right)$, previously obtained with the following equation: $L_{c}=L_{\text {inf }}$ $\left\{1-e\left[-K\left(t_{50 \%}-t_{0}\right)\right]\right\}$, where Lc is the length of the first catch and $t_{50 \%}$ is the average capture age.

Confidence intervals were established at 95\% for $\mathrm{L}_{\text {inf }} \mathrm{K}$ and $\mathrm{Z}$, as well as for the morphometric relationships SL-TL, FL-TL and SL-FL. Each of these regressions is estimated for a correlation coefficient $(r)$, and the determination $\left(r^{2}\right)$ for $Z$.

\section{RESULTS}

Between January 2001 and December 20021893 individuals were collected (Table 1 ), information that was combined to improve quality. The minimum length collected was $13.6 \mathrm{~cm}$ TL (July 2002) and the maximum length was 41.5 $\mathrm{cm}$ TL (January 2002). The length frequency distribution shows a bimodal curve normally distributed in both cases with modal frequencies of 22.0 and $34.0 \mathrm{~cm}$ TL (Figure 1).

Linear regressions obtained with $95 \%$ confidence (Figure 2) were:

$$
\begin{aligned}
& \mathrm{TL}=0.91( \pm 0.01)+1.17( \pm 0.005) \mathrm{SL} \\
& \mathrm{TL}=0.31( \pm 0.06)+1.09( \pm 0.003) \mathrm{FL} \\
& \mathrm{FL}=0.58( \pm 0.08)+1.07( \pm 0.004) \mathrm{SL}
\end{aligned}
$$

En donde, e es la base del logaritmo neperiano, $\mathrm{N}$ es el número de peces en la muestra, $\Delta t$ es el intervalo de tiempo necesario para que un pez pase de una talla a otra, a es el intercepto de la regresión, b es la pendiente de la regresión y $\mathrm{t}$ es la edad media relativa. La curva de captura se construyó con los valores promedios estimados anteriormente para los parámetros de crecimiento, trazándose la línea de regresión sobre los puntos ubicados en la parte descendente de la curva, en donde la tasa instantánea de mortalidad (Z) es la pendiente (b) con signo cambiado. El intervalo de confianza al $95 \%$ y el coeficiente de determinación se obtuvieron teniendo en cuenta únicamente los valores en $\mathrm{x}$ e y involucrados en la regresión.

La tasa instantánea de mortalidad natural (M) se estimó con la ecuación (3):

$$
\begin{aligned}
& \log _{10} M=-0.0066-0.279 \log _{10} L_{\text {inf }}+0.6543 \log _{10} \\
& K+0.4634 \log _{10} T
\end{aligned}
$$

En donde T es la temperatura media anual del agua, medida con un equipo multi parámetro portátil (Hanna Instruments, USA). La tasa instantánea de mortalidad por pesca $(F)$ se calculó con $F=Z-M$ y la tasa de explotación (E) se obtuvo con la relación $E=F / Z$, y son rutinas que hacen parte de ELEFAN II (4). Para estimar el patrón de selección y reclutamiento se aplicó la metodología de Tresierra \& Culquichicón (7), utilizando los datos de longitud asintótica $\left(\mathrm{L}_{\text {inf }}\right)$, coeficiente de crecimiento (K) y la edad a la longitud cero $\left(t_{0}\right)$, obtenidos anteriormente, con la siguiente ecuación: $L_{c}=L_{\text {inf }}$ $\left\{1-e\left[-K\left(t_{50 \%}-t_{0}\right)\right]\right\}$, en donde Lc es la longitud de primera captura y $\mathrm{t}_{50 \%}$ es la edad media de captura.

Se establecieron intervalos de confianza al $95 \%$ para $L_{\text {inf }}, K$ y $Z$, al igual que para las relaciones morfométricas LS-LT, LH-LT y LS-LH. A cada una de estas regresiones se les estimó el coeficiente de correlación $(r)$, y el de determinación $\left(r^{2}\right)$ para $Z$.

\section{RESULTADOS}

Se colectaron 1893 individuos entre enero 2001 y diciembre 2002 (Tabla 1), información que debió fusionarse para mejorar su calidad. La talla mínima colectada fue $13.6 \mathrm{~cm}$ LT (julio 2002) y la talla máxima $41.5 \mathrm{~cm}$ LT (enero 2002). La distribución de frecuencia de tallas presenta una curva bimodal normalmente distribuida en ambos casos, con frecuencias modales de 22.0 y 34.0 cm LT (Figura 1).

Las regresiones lineales obtenidas con el $95 \%$ de confianza (Figura 2) fueron:

$\mathrm{LT}=0.91( \pm 0.01)+1.17( \pm 0.005) \mathrm{LS}$ 
Table 1. Length frequency data of Cachana in the Ciénaga Grande de Lorica..

\begin{tabular}{|c|c|c|c|c|c|c|c|c|c|c|c|c|c|}
\hline $\begin{array}{l}\text { length } \\
\text { (cm TL) }\end{array}$ & Jan & Feb & Mar & April & May & June & July & Aug & Sep & Oct & Nov & Dec & Total \\
\hline 14 & 0 & 0 & 0 & 0 & 0 & 0 & 5 & 0 & 0 & 0 & 0 & 0 & 5 \\
\hline 15 & 0 & 0 & 0 & 0 & 0 & 0 & 9 & 0 & 1 & 0 & 0 & 0 & 10 \\
\hline 16 & 0 & 0 & 0 & 0 & 0 & 1 & 19 & 6 & 1 & 0 & 0 & 0 & 27 \\
\hline 17 & 6 & 0 & 0 & 0 & 0 & 0 & 30 & 24 & 5 & 2 & 0 & 0 & 67 \\
\hline 18 & 2 & 0 & 0 & 0 & 0 & 0 & 28 & 30 & 15 & 12 & 4 & 2 & 93 \\
\hline 19 & 3 & 0 & 0 & 0 & 0 & 1 & 10 & 28 & 31 & 24 & 9 & 6 & 112 \\
\hline 20 & 4 & 1 & 2 & 0 & 0 & 1 & 4 & 27 & 31 & 31 & 44 & 13 & 158 \\
\hline 21 & 8 & 2 & 2 & 1 & 1 & 2 & 1 & 20 & 23 & 34 & 53 & 28 & 175 \\
\hline 22 & 14 & 8 & 0 & 3 & 3 & 0 & 1 & 9 & 36 & 46 & 51 & 42 & 213 \\
\hline 23 & 14 & 19 & 3 & 7 & 7 & 0 & 0 & 3 & 26 & 29 & 35 & 30 & 173 \\
\hline 24 & 22 & 26 & 2 & 2 & 3 & 2 & 3 & 4 & 19 & 22 & 25 & 20 & 150 \\
\hline 25 & 5 & 15 & 8 & 12 & 7 & 0 & 1 & 6 & 7 & 12 & 15 & 17 & 105 \\
\hline 26 & 2 & 8 & 11 & 5 & 4 & 4 & 2 & 4 & 5 & 6 & 5 & 8 & 64 \\
\hline 27 & 3 & 1 & 4 & 0 & 0 & 0 & 7 & 3 & 16 & 10 & 6 & 12 & 62 \\
\hline 28 & 1 & 6 & 0 & 7 & 4 & 3 & 6 & 2 & 4 & 6 & 1 & 9 & 49 \\
\hline 29 & 0 & 4 & 0 & 3 & 1 & 2 & 6 & 0 & 3 & 1 & 0 & 4 & 24 \\
\hline 30 & 1 & 6 & 0 & 3 & 3 & 1 & 1 & 5 & 2 & 2 & 1 & 9 & 34 \\
\hline 31 & 1 & 1 & 0 & 0 & 0 & 1 & 1 & 3 & 0 & 2 & 0 & 1 & 10 \\
\hline 32 & 4 & 3 & 2 & 2 & 1 & 3 & 2 & 2 & 4 & 1 & 2 & 1 & 27 \\
\hline 33 & 7 & 5 & 4 & 6 & 3 & 3 & 5 & 4 & 2 & 1 & 2 & 5 & 47 \\
\hline 34 & 9 & 8 & 8 & 6 & 8 & 7 & 6 & 4 & 2 & 1 & 0 & 0 & 59 \\
\hline 35 & 7 & 7 & 7 & 2 & 2 & 6 & 8 & 3 & 3 & 4 & 2 & 4 & 55 \\
\hline 36 & 4 & 11 & 8 & 4 & 4 & 5 & 5 & 4 & 6 & 3 & 1 & 1 & 56 \\
\hline 37 & 6 & 3 & 12 & 3 & 3 & 5 & 4 & 6 & 6 & 2 & 1 & 4 & 55 \\
\hline 38 & 7 & 3 & 4 & 2 & 1 & 2 & 3 & 2 & 2 & 3 & 1 & 0 & 30 \\
\hline 39 & 0 & 1 & 4 & 1 & 1 & 2 & 4 & 2 & 3 & 4 & 1 & 0 & 23 \\
\hline 40 & 1 & 0 & 0 & 0 & 0 & 0 & 0 & 2 & 3 & 0 & 0 & 0 & 6 \\
\hline 41 & 0 & 0 & 0 & 0 & 0 & 0 & 0 & 0 & 1 & 0 & 0 & 2 & 3 \\
\hline 42 & 1 & 0 & 0 & 0 & 0 & 0 & 0 & 0 & 0 & 0 & 0 & 0 & 1 \\
\hline TOTAL & 132 & 138 & 81 & 69 & 56 & 51 & 171 & 203 & 257 & 258 & 259 & 218 & 1893 \\
\hline
\end{tabular}

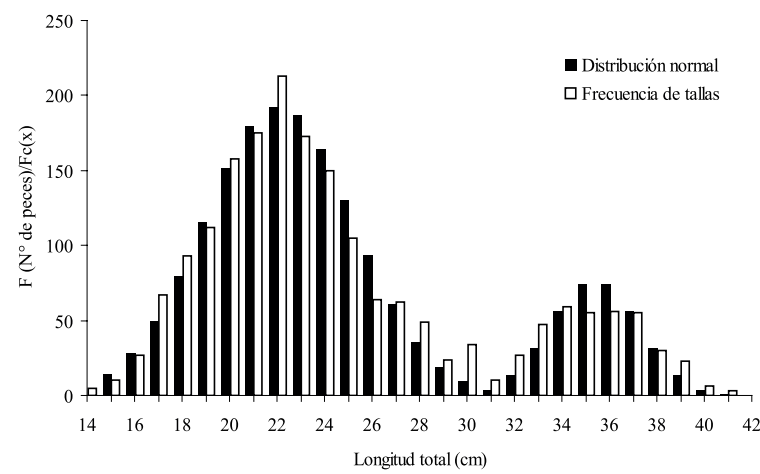

Figure 1. Length frequency distribution of Cachana.

The length-weight relationship (Figure 3 ) was

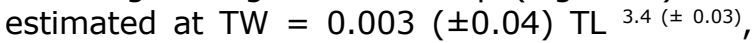
$r=0.99, n=1893$ ), with a positive allometric growth coefficient. The estimated values for $L_{\text {inf }} K$ and $t_{0}$ to the growth equation were $43.4( \pm 0.52) \mathrm{cm} \mathrm{TL}$, $0.29( \pm 0.02)$ year $^{-1}$ and -0.53 years, respectively, with average annual temperatures of $28^{\circ} \mathrm{C}$ and confidence limits at $95 \%$. The value of $t_{0}$ is low and is not significantly different from zero $(p>0.05)$.

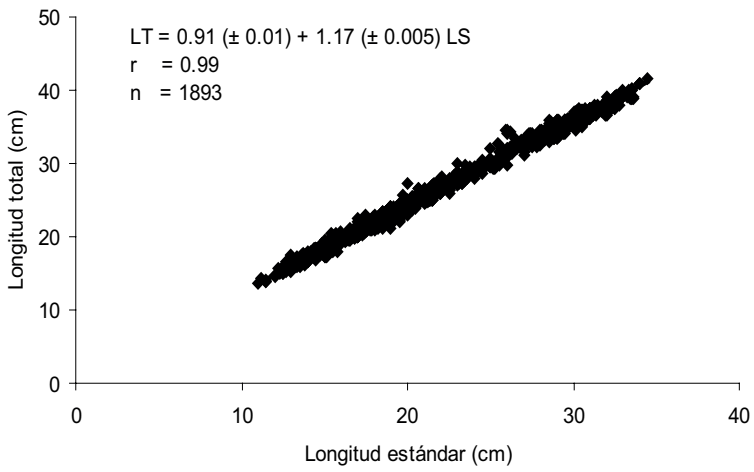

Figure 2. Length-length relationship of Cachana.

$\mathrm{LT}=0.31( \pm 0.06)+1.09( \pm 0.003) \mathrm{LH}$

$\mathrm{LH}=0.58( \pm 0.08)+1.07( \pm 0.004) \mathrm{LS}$

La relación longitud-peso (Figura 3 ) se estimó en

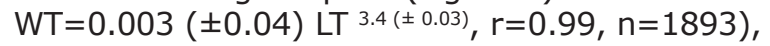
con coeficiente de crecimiento alométrico positivo. Los valores estimados para $\mathrm{L}_{\text {inf }} \mathrm{K}_{\mathrm{K}} \mathrm{t}$ de la ecuación de crecimiento fueron $43.4( \pm 0.52) \mathrm{cm} L T, 0.29$ $( \pm 0.02)$ año $^{-1}$ y -0.53 años, respectivamente, con 


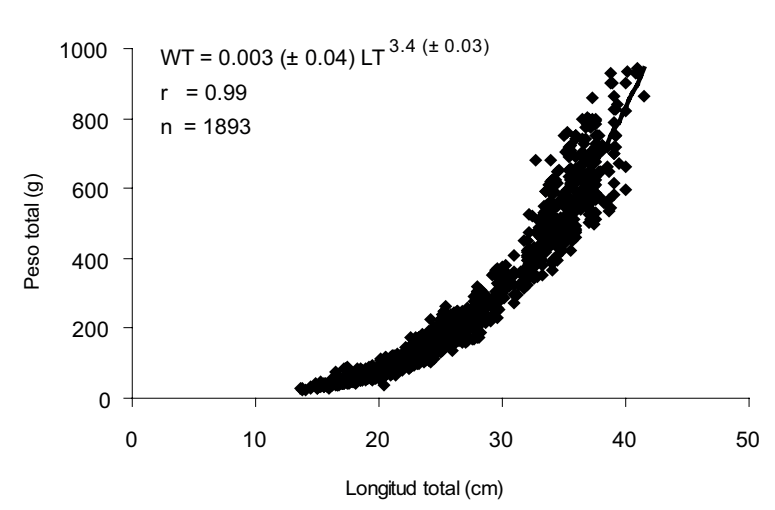

Figure 3. Length-weight relationship of Cachana.

In table 2 the length-at-age key is presented, with whose data the growth curve was drawn (figure 4). The growth performance index $\left(\varnothing^{\prime}\right)$ was 2.73. In figure 5 it is possible to observe the length converted in catch curve and the corresponding regression. The estimated instantaneous rates were: $0.97( \pm 0.16) \mathrm{yr}^{-1}$ for total mortality $(Z), 0.72( \pm 0.03) \mathrm{yr}^{-1}$ for natural mortality $(M)$ and $0.25 \mathrm{yr}^{-1}$ for capture mortality (F) with $95 \%$ of confidence for all three values.

The average catch length estimated for Cachana was $24.8 \mathrm{~cm} \mathrm{TL}$, recruited to the fishery $\left(L_{c}\right)$ at $16.6 \mathrm{~cm}$ TL (Figure 6 ), with an exploitation rate of 0.26 .

Tabla 2. Length-at-age key.

\begin{tabular}{cc}
\hline $\mathbf{t}$ (years) & $\mathbf{T L}(\mathbf{c m})$ \\
\hline 0.0 & 6.2 \\
1.0 & 12.7 \\
2.0 & 18.0 \\
3.0 & 22.5 \\
4.0 & 26.1 \\
5.0 & 29.1 \\
6.0 & 31.6 \\
7.0 & 33.7 \\
\hline
\end{tabular}

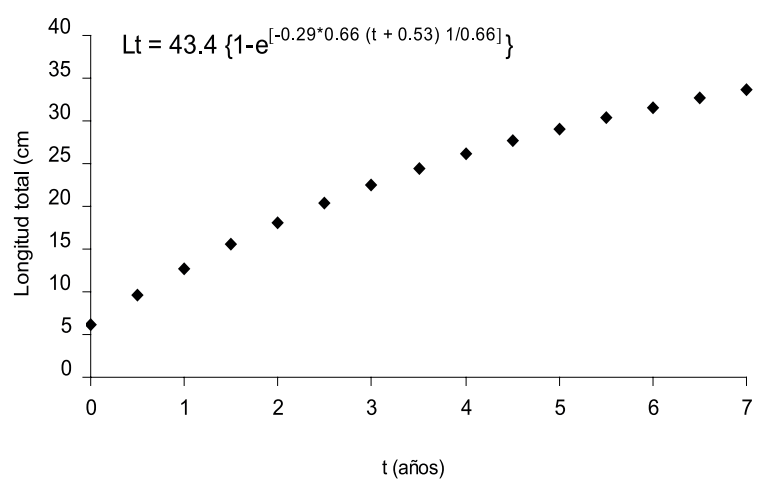

Figure 4. Von Bertalanffy growth curve. temperatura media anual de $28^{\circ} \mathrm{C}$ y límites de confianza del $95 \%$. El valor de $t_{0}$ es bajo y no es significativamente diferente de cero $(p>0.05)$.

En la tabla 2 se presenta la clave talla-edad, con cuyos datos se trazó la curva de crecimiento (figura 4). El Índice de desempeño del crecimiento $\left(\varnothing^{\prime}\right)$ fue 2.73. En la figura 5 se observan las tallas convertidas en curva de captura y su correspondiente regresión. Las tasas instantáneas estimadas fueron las siguientes: $0.97( \pm 0.16)$ año${ }^{1}$ para la mortalidad total $(Z), 0.72( \pm 0.03)$ año $^{-1}$ para la mortalidad natural (M) y 0.25 año ${ }^{-1}$ para la mortalidad por captura (F), con 95\% de confianza para los tres valores.

La talla media de captura estimada para la Cachana fue $24.8 \mathrm{~cm} \mathrm{LT}$, siendo reclutada a la pesquería $\left(\mathrm{L}_{c}\right)$ con $16.6 \mathrm{~cm}$ LT (Figura 6), con tasa de explotación de 0.26 .

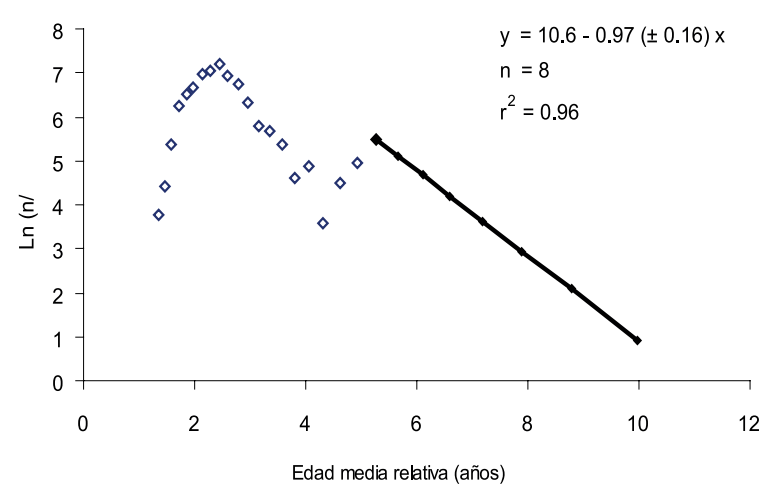

Figure 5. Length converted in catch curve of Cachana. $\diamond$ Used $\diamond$ Not used.

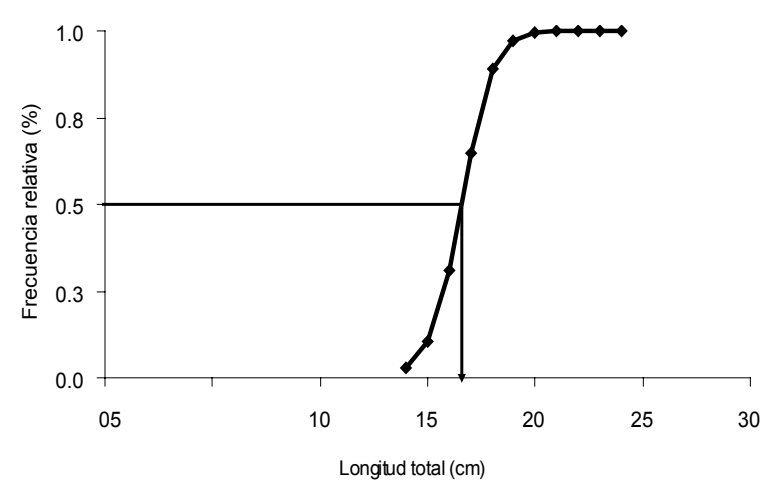

Figure 6. Catch selection curve. 


\section{DISCUSSION}

The length frequency distribution presents a normally distributed curve, where the estimated values for asymptotic length $\left(L_{\text {inf }}=43.4 \mathrm{~cm} \mathrm{TL}\right)$ and the growth coefficient $\left(K=0.29 \mathrm{yr}^{-1}\right)$ make it possible to infer that Cachana is a fish with average longevity and growth rate, taking into account the life cycle parameters for stocks reported by Musick (8).

The estimated growth rate for the total length-total weight relationship shows that species growth under study is not isometric (b>3.0). This, and the fact that two curves in the length frequency distribution can be seen, suggests that the species makes lateral trophic or reproductive migrations in the Ciénaga Grande de Lorica to a still undisclosed location. All processes operating in floodplains are closely related to the hydrological regime, where alternation between periods of drought and flooding determines the structure and functioning of these environments (9-10). The influence of hydrological cycle attributes on migration, reproduction, juvenile survival and recruitment has been widely discussed by other authors (11-12).

In rivers with flood plains, fishery production tends to be strongly related to flooding intensity (13), which was observed in this study where the species caught in this study fluctuated in the Sinú basin between 9.1, 54.8, 8.8, 4.0 and 3.4 tons between 1997 and 2002, respectively (14-18). Additionally, in 2001 and 2002 in the fishery it was found that $75.5 \%$ (1429 individuals) of the catch was below the minimum catch length established for the Ciénaga Grande de Lorica and the Sinú River basin, $23.0 \mathrm{~cm} \mathrm{SL}(27.8 \mathrm{~cm} \mathrm{TL})$, by means of Resolution 000520 from November 8, 2001 (19).

However, according to the length-at-age key estimated, the species under study is recruited entirely to the fishery $\left(L_{c}=16.6 \mathrm{~cm} \mathrm{TL}\right)$ at 1.7 years, with a low exploitation rate $(E=0.26)$, so it appears that there is still no overfishing considering that the optimal value for the exploitation rate is 0.5 and corresponds to a resource that is not being exploited in a disorganized or irrational way, which argues against the current regulations in the country. The minimum catch length established for Ciénaga Grande de Lorica and the Sinú Basin $(23.0 \mathrm{~cm} \mathrm{SL}, 27.8 \mathrm{~cm} \mathrm{TL}$ ) corresponds to the average length found in the length frequency distribution with a bimodal curve normally distributed as estimated in this study (22.0

\section{DISCUSIÓN}

La distribución de frecuencia de tallas presenta una curva normalmente distribuida, en donde los valores estimados para la talla asintótica $\left(\mathrm{L}_{\text {inf }}=43.4\right.$ $\mathrm{cm}$ LT) y el coeficiente de crecimiento $(\mathrm{K}=0.29$ año ${ }^{-1}$ ) permiten inferir que la Cachana es un pez de longevidad y tasa de crecimiento medios, teniendo en cuenta los parámetros del ciclo de vida para poblaciones de peces reportados por Musick (8).

El coeficiente de crecimiento estimado para la relación longitud total-peso total, muestra que el crecimiento de la especie en estudio no es isométrico $(b>3.0)$. Esto, y el hecho de observarse dos curvas en la distribución de frecuencia de tallas, sugieren que la especie realiza migraciones laterales tróficas o reproductivas de la ciénaga Grande de Lorica hacia un lugar no determinado a la fecha. Todos los procesos que operan en las llanuras de inundación están estrechamente relacionados con el régimen hidrológico, en donde la alternancia entre inundaciones y períodos de sequía determina la estructura y funcionamiento de estos ambientes $(9-10)$. La influencia de los atributos del ciclo hidrológico sobre la migración, reproducción, supervivencia juvenil y reclutamiento ha sido ampliamente discutida por otros autores (11-12).

En los ríos con planos inundables, la producción pesquera tiende a estar fuertemente relacionada con la intensidad de las inundaciones (13), lo cual se observó en este trabajo en donde la captura de la especie en estudio ha mostrado fluctuaciones en la cuenca del Sinú de 9.1, 54.8, 8.8, 4.0 y 3.4 toneladas entre los años 1997 y 2002, respectivamente (14-18). Sumado a lo anterior, se encontró que durante los años 2001 y 2002 en la pesquería de la Cachana, el 75.5\% (1429 individuos) de la captura se realizó por debajo de la talla mínima de captura establecida para la ciénaga Grande de Lorica y la cuenca del Sinú en $23.0 \mathrm{~cm}$ LS ( $27.8 \mathrm{~cm} \mathrm{LT}$ ) mediante la Resolución 000520 de noviembre 8 del 2001 (19).

Sin embargo, de acuerdo con la clave talla-edad estimada, la especie en estudio es reclutada totalmente a la pesquería $\left(\mathrm{L}_{\mathrm{c}}=16.6 \mathrm{~cm} \mathrm{LT}\right)$ a los 1.7 años de vida, con baja tasa de explotación $(E=0.26)$, por lo que infiere que aún no hay sobrepesca sobre el recurso teniendo en cuenta que el valor óptimo para la tasa de explotación es de 0.5 y corresponde a un recurso que no se está explotando desordenada o irracionalmente, lo cual controvierte la normatividad vigente en el país. La talla mínima de captura establecida para la ciénaga Grande de Lorica y la cuenca del Sinú $(23.0 \mathrm{~cm}$ LS, $27.8 \mathrm{~cm} \mathrm{LT}$ ) corresponde al promedio de las tallas encontradas en la distribución de frecuencia de tallas con curva 
and $34.0 \mathrm{~cm} \mathrm{TL}$ ). Therefore, it is inferred that biases could exist in the estimation of the minimum catch length established for the species if not enough larger fish were collected that correspond to older specimens of the species in question.

Therefore, the results of this study should be discussed with the fishery authority in Colombia (AUNAP) to analyze if the current legal minimum catch size established by Resolution 000520 is indeed consistent with the biology of this species. If most of fishing was focused on individuals below the legal size, the rate of exploitation would be very high, above 0.5 , which is the optimum level of exploitation, and would result in overfishing; this was not observed in this study. A review, update and/or adjustment of the standard should be suggested to the AUNAP so that the fish can be caught following duly estimated growth parameters.

Unlike commercially important fish species in the Sinú River basin, Cachana is not reported in fishery monitoring studies of INPA-Urrá agreement as a fish with commercial interest, so there is little biological information regarding its growth, mortality, feeding habits and reproductive biology. However, since it is a very important fish for the food security of fishermen and their families, as well as for those who sell fish in the market places or on the streets throughout Bajo Sinú, it is necessary, as for the most commercially important species, to research on its biology and ecology for the adequate management and conservation of the species in the cienaga and the Sinu River basin.

\section{Acknowlegements}

To the fishermen and fish traders in the Ciénaga Grande de Lorica and the lower Sinú River basin, and to the researchers involved in the "Estimación de los parámetros biológicos básicos de peces comerciales del Río SinúFase II" project, Code FMV-01-04, Number 1120107, which formed part of this study. To the Universidad de Córdoba for the funding received. bimodal normalmente distribuida estimada en este trabajo (22.0 y $34.0 \mathrm{~cm} \mathrm{LT}$ ). Por tanto, se infiere que pudo haber sesgos en la estimación de la talla mínima de captura establecida para la especie al no colectarse suficientes peces con tallas más grandes correspondientes a cohortes de mayor edad de la especie en mención.

Por lo anterior, los resultados de este trabajo deberían discutirse con la autoridad de pesca en Colombia (AUNAP), para analizar si en verdad la actual talla mínima legal de captura establecida por la Resolución 000520, es acorde con la biología de esta especie, puesto que si la mayor parte de la pesquería se centró en individuos por debajo de la talla legal establecida, se esperaría que la tasa de explotación fuese muy alta, mayor de 0.5 , que es el nivel óptimo de explotación, lo que se traduciría en sobrepesca sobre el recurso; lo que no se observó en este trabajo. Se debería promover ante la AUNAP una revisión, actualización y/o ajuste de la norma, para que de esta manera la pesquería de la especie se realice siguiendo parámetros de crecimiento adecuadamente estimados.

A diferencia de los peces comercialmente importantes en la cuenca del río Sinú, la Cachana no es reportada en los estudios de monitoreo pesquero del Convenio INPA-Urrá como un pez de interés comercial, por lo que se tiene poca información biológica básica con respecto a su crecimiento, mortalidad, hábitos alimentarios y biología reproductiva. Sin embargo, como es un pez muy importante en la seguridad alimentaria de los pescadores y sus familias, así como de quienes comercializan el pescado en las plazas de mercado o a nivel callejero en todo el Bajo Sinú, es necesario, al igual que para con las especies de mayor importancia comercial, investigar sobre su biología y ecología para el manejo y conservación de la especie en la ciénaga y la cuenca del río Sinú.

\section{Agradecimientos}

A los pescadores y comercializadores de pescado de la ciénaga Grande de Lorica y de la cuenca baja del río Sinú y a los investigadores involucrados en el proyecto "Estimación de los parámetros biológicos básicos de peces comerciales del Río Sinú-Fase II", Código FMV-01-04, Numeral 1120107, del cual hace parte este trabajo. A la Universidad de Córdoba, por la financiación recibida. 


\section{REFERENCES}

1. Eigenmann $\mathrm{CH}$, Ogle F. An annotated list of characin fishes in the United States national museum and the museum of Indiana University, with descriptions of new species. Proc US Natl Mus 1907; 33: 1-36.

2. Sparre P, Venema SC. Introducción a la evaluación de recursos pesqueros tropicales. Parte 1. Manual. FAO Doc Téc de Pesca 1997; 306/1(rev.2): 1-420.

3. Pauly D. 1983. Algunos métodos simples para la evaluación de recursos pesqueros tropicales. FAO Doc Téc de Pesca 1983; 234: 1-49.

4. Gayanilo FC Jr, Soriano M, Pauly D. A draft guide to the compleat ELEFAN. ICLARM Contribution 1988; 435: 1-70.

5. Von Bertalanffy L. A quantitative theory of organic growth. Hum Biol 1938; 10 (2): 181-213.

6. Pauly D, Munro JL. Once more in the comparisons of the growth in fish and invertebrates. Fishbyte 1984; 2 (1): 21.

7. Tresierra $A E$, Culquichicón ZG. Manual de biología pesquera. Trujillo: Concytec 1995.

8. Musick JA. Criteria to define extinction risk in marine fishes. Fisheries 1999; 24: 6-14.

9. Thomaz SM, Bini LM, Bozelli RL. Floods increase similarity among aquatic habitats in river-floodplains systems. Hydrobiologia 2007; 579 (1): 1-13.

10. Raniere G, Souza C, Freitas ECF. The influence of flood pulse on fish communities of floodplain canals in the Middle Solimões River, Brazil. Neotrop Ichthyol 2008; 6 (2): 249-255.

11. Agostinho AA, Pelicice FM, Petry AC, Gomes LC, Júlio Jr HF. Fish diversity in the upper Paraná River basin: habitats, fisheries, management and conservation. Aquat Ecosyst Health Manag 2007; 10 (2): 174-186.
12. Gubiani ÉA, Gomes LC, Agostinho AA, Okada EK. Persistence of fish population in the upper Paraná River: effects of water regulation by dams. Ecol Freshw Fish 2007; 16 (2): 191-197.

13. Welcomme RL, Bene C, Brown CA, Arthington A, Dugan P, King JM, et al. Predicting the water requirements of river fisheries. In: Verhoeven JTA, Beltman B, Bobbink R, Whigham DF. (eds.). Berlin: Springer Verlag. Wetlands and natural resource management. Ecological Studies 2006; 190: 123-154.

14. Valderrama M, Ruiz O. Evaluación de la captura y esfuerzo y determinación de información biológico pesquera de las principales especies ícticas en las áreas de Lorica, Betancí y Tierralta. Montería: Informe presentado a Urrá S.A. E.S.P., 1998.

15. Valderrama M, Ruiz O. Monitoreo pesquero del Medio y Bajo Sinú. Montería: Informe presentado a Urrá S.A. E.S.P.; 1999.

16. Valderrama M, Ruiz O. Resultados comparativos del monitoreo pesquero del Medio y Bajo Sinú (1997-2000). Montería: Informe presentado a Urrá S.A. E.S.P.; 2000.

17. Valderrama M, Vejarano S. Monitoreo y estadística pesquera en la cuenca del Río Sinú con participación comunitaria. Cuarto año pesquero. Montería: Informe final período marzo 2000-febrero 2001 presentado a Urrá S.A. E.S.P.; 2001.

18. Valderrama M. Monitoreo y estadística pesquera en la cuenca del Río Sinú con participación comunitaria. Quinto año pesquero. Montería: Informe final período marzo 2001-febrero 2002 presentado a Urrá S.A. E.S.P.; 2002.

19. INPA. Resolución 000520 de 08 de Noviembre 2001. Bogotá: Instituto Nacional de Pesca y Acuicultura. 2001. 